Acta vet. scand. $1960,1,250-276$.

From the Department of Biochemistry, the Veterinary College of Norway, Oslo.

THE OCCURRENCE OF CONDITIONED AND SIMPLE COPPER DEFICIENCY IN CATTLE AND SHEEP IN SETESDALEN, A VALLEY IN THE SOUTHERN PART OF NORWAY

By

Gustav N. Havre, Olav Dynna and Fredr. Ender.

The study of etiological factors in connection with the copper deficiency syndrome in domestic animals has revealed that it is necessary to differentiate between a real, simple or uncomplicated copper deficiency, due to a low content of copper in the diet and a more or less "conditioned" copper deficiency, where conditioning factors are acting upon copper metabolism, with the result that symptoms of copper deficiency are produced, although the diet is adequate in copper.

The first indication of conditioning factors involved in hypocuprosis in cattle, was the discovery by Ferguson \& al. $(1938,1943$ and 1945) that copper is able to cure the profused scouring occurring on "Teart" in the Somerset district, due to an excess of molybdenum in pasture.

Scouring in cattle, combined with disturbances in the copper metabolism, have been reported from many parts of the world, especially from England, Holland, Australia, New Zealand, U. S. A. and Canada. Already in 1933 Sjollema in Holland reported symptoms of scouring in cattle in relation to copper deficiency.

The importance of an interrelationship between molybdenum and copper in connection with scouring in cattle and enzootic ataxia (Swayback) in lambs, has been discussed by various research workers - especially Ferguson, Allcroft and Cunningham.

Supposed the copper content of the diet is normal or subnormal, increased levels of dietary molybdenum will reduce the amount of copper already stored in the liver. The lower the copper content is, the lesser amount of molybdenum is necessary to produce this effect. On the other hand, raised copper content in the diet will reduce the 
molybdenum content of the liver. In what way molybdenum interferes with copper metabolism is still obscure. Some authors have suggested that copper is fixed by molybdenum in a physiological inaccessible form.

Dick in Australia (1952 and 1953) claims that molybdenum can only limit the storage of copper in the liver of sheep, when adequate amounts of inorganic sulphate is also present in the diet.

Copper deficiency in connection with pica in cattle was at first reported by Sjollema in Holland (1933). In Norway, Ender (1942) found low copper values in hay and grass, i.e. values below 4.5 p.p.m. varying from 1.3-4.0 p.p.m., associated with a form of pica. This type of pica, where scouring symptoms do not occur, is obviously more related to low levels of dietary cobolt than to copper, since treatment with cobolt generally exerts a better effect than one-sided theraphy with copper. It seems, therefore, correct to suppose that cobolt should be designated as the limiting factor in this disorder.

Conditioned copper deficiency was at first observed in relation to feeding of "Teart" or "Tart" herbage in Somerset in England. On New Zealand pastures, molybdenosis in cattle was found accociated with a low content of copper in the diet. On the basis of analyses of diets, carried out in Australia and New Zealand Cunningham (1955) reported that in these countries copper values above 5 p.p. m. are considered sufficient if conditioning factors are not present. This statement is in good agrement with investigations carried out in Norway.

With respect to molybdenum, values show 3 p.p. m. are considered by Cunningham to be harmless. 3-10 p. p. m. molybdenum is considered to be harmful if the copper content is below normal. More than 10 p. p. m. molybdenum is harmful when the copper content is normal. The sulphur content in some of the pastures in New Zealand, where copper deficiency occurs, with or without excess of molybdenum, varies between $0.07-0.25$ per cent, calculated on dry matter basis.

Allcroft (1957) has in an excellent review discussed the very complicated etiology involved in connection with swayback in lambs and hypocuprosis occurring in cattle in relation to various conditioning factors. Field (1957) has reported that conditioned copper deficiency occurs in East Anglia in cattle grazing on black fen over peat or sand with some areas of sand.

Henderson (1957) found the same in East Ontario - on badly drained ground with a high content of organic material in the soil. In this case, the land was burnt over prior to cultivating. The term "Teart" or "Tart" is a local name of affected pastures in Somerset. The soil in Somerset is acid. Lewis (1943) has pointed to the fact that the highest molybdenum content in pastures, i. e. $10-100$ p. p. m., was found on alkaline soils. It should also be borne in mind that liming of the soil, resulting in increased soil alkalinity, contributes strongly to increase the molybdenum uptake by the herbage. Different plant species have different capacities for absorbing minerals. Clover 
is richer in copper than the grass species but, on the other hand, is also rich in molybdenum.

Conditioned copper deficiency arising from an abnormal dietary $\mathrm{Cu} /$ Mo-relationship is generally characterized by low blood copper values and low liver copper values. Symptoms of diarrhoea occur constantly or for periods in cattle. Depigmentation of the hair-layer in cattle and achromotrichia in black-wooled sheep in common. That a high molybdenum content in pasture can produce diarrhoea with general unthriftiness, curable with copper supplies, seems to be a well established fact according to various research workers. The syndrome of copper deficiency associated with diarrhoea is further proved by feeding experiments in which high levels of molybdenum have been dosed, as well as from incidences of industrial molybdenosis (Buxton \& Allcroft, 1955, Parker \& Rose, 1955, Hallgren, Karlsson \& Wramby 1954).

Field, who carried out his investigations on beef cattle, found that the disease most frequently occurred in animals in the period of intensive growth. The animals showed a stilted gait, enlargement of the fet lock joint, fading of the hair-layer and occasional diarrhoea. Other characteristics were decreased appetite and loss of condition. In Eastern Ontario, Henderson (1957) observed diarrhoea in most of the cases, fading of the hair-layer, decreased milk yield and reduced growth gain. Disturbances of the oestral cyclus, in some cases leading to temporary sterility, are stated to have occurred in Australia. Cunningham refers to have observed copper deficiency, associated with anaemia in ewes in New Zealand. The wool looses its crimps and becomes glassy and steely in appearance. Lambs up to four months of age can develop enzootic ataxia (Swayback) with a spastic diplegia, incoordination of movements and blindness, due to a symmetric demyelination of cerebrum and the motor tract of the cord. Cunningham considers swayback as being incurable, but Grace \& Todd (1958) observed 6 cases of swayback in a sheepstock in Ireland, where 4 cases went to health. The authors found low blood copper figures in the mothers of lambs suffering from swayback. According to Robertson (1957), swayback is seen in England on pastures adequate in copper and with only little correlation to molybdenum. The same has been found by Allcroft (1957).

The present paper gives a description of conditioned copper deficiency observed for the first time in Norway. As simple copper deficiency has also been proved in some places, this is dealt with in order to compare it with the conditioned form. The diseases appear in Setesdalen, a valley in the Southern part of Norway. It may be worth while mentioning that in a single grass sample from a neighbouring district, situated east of Setesdalen, a relatively high molybdenum content and a low copper content were also found. 


\section{COPPER DEFICIENCY IN SETESDALEN}

The first cases of a disorder in cattle characterized by unthriftiness and scouring - and curable by treatment with copper - were observed by one of us (Dynna) in the autumn 1957.

These observations gave rise to investigations carried out during the years 1957-1959, described in detail in this paper. Through these investigations it became apparent that hypocuprosis plays a much bigger role in the unthriftiness problem in Setesdalen than at first supposed. It was hardly the first of all cases having occured in this locality, but it may be stated with certainty that conditioned copper deficiency in earlier days played a less important role than nowadays. It is only in the last couple of decades, particularly after the last world war, that this disease has actually become a problem.

Before giving a description of the occurrence of disorder in relation to mineral levels from plant and soil analyses which have been carried out, it seems pertinent to give a short description of the topography and the type of soil found in this valley. As changes in the mode of farming and husbandry in recent years seem to be related to the increased occurrence of this disorder, a short commentary is necessary.

\section{Topography.}

Setesdalen is a long, U-shaped valley with steep, polished, rocky walls on both sides.

The soil in Setesdalen is mainly morena soil, colluvium or debrissoil arising from landslides on the hill sides, and river sediments in the bottom of the valley, where the river Otra is running in a Southern direction. There are also a few small areas of fenland. With the exception of the flat pieces of land, situated close to the river bank, the cultivated land in Setesdalen is rarely exposed to submersion. The rock in Setesdalen consist mainly of granite of different kinds, often rich in iron. Other rocks are gneiss, quartz, glimmer, gabbro etc., which are found here and there in the valley. As far as the authors know, limestone has not been found in Setesdalen. In quite a few places pyrite is found in the rock, mostly as copper pyrite besides molybdena.

Many years ago some mining, especially copper mining, was going on in Setesdalen in the mountains surrounding the valley. (Kummen 1916, Neumann 1954).

\section{Agriculture.}

The cultivated land in Setesdalen consists mainly of sand, with varying contents of humus, cultivated for generations. The natural drainage is good and the land can yield good crops. The top-soil 


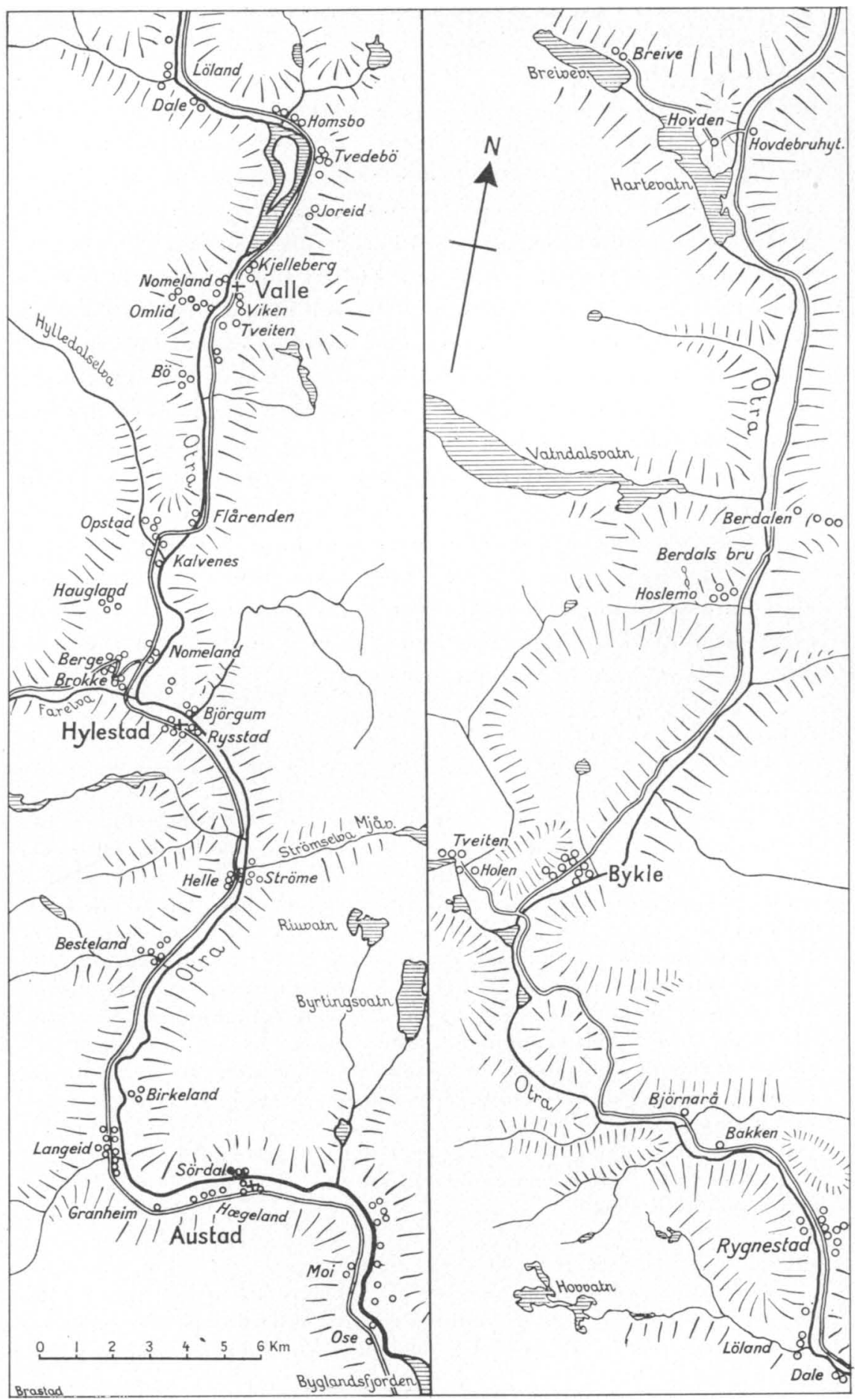


layer is usually from $20-30 \mathrm{~cm}$ deep, sometimes deeper. The soil is easily improvable but, farming in Setesdalen is still primitive, e.g. the rotation of crops not being very common. The land is usually kept for meadows for 10-20 years or longer, before it is rotated.

Previously, the flat land in the bottom of the valley was used for grain production, while the hill sides were used as pasture and meadow. At that time, the farmers also collected hay from the mountains, from areas covering several hundred acres. Today this type of farming is being altered, but still some of the cattle are taken to the mountains during the summer for grazing. When the farmers ceased to collect hay in the mountain regions - about 15-20 years ago - they started cultivating the old river banks for hay production and pasture, and the cereal production decreased. These changes of farming, especially the use of the old river banks for grass production, seem, according to our opinion, to have contributed to increase the occurrence of conditioned copper deficiency.

Fertilization is simple and scanty. Only a few farmers lime the soil and nobody does it regulary. As a consequence the soil is sour all over. The dressing is mainly a complete fertilizer containing $\mathrm{N}-\mathrm{K}$ and $P$, very often with farm manure in addition.

As a consequence of the long rotation periods a pure timothy or clover meadow is rarely found. Very often the meadows are natural meadows, with a beautiful variety of flowers. Timothy together with different fescue species are found on young meadows. The meadows are commonly used for grazing in the spring time and during the later part of the summer. Frame drying of the hay is used, but the farmers prefer ground or hill drying.

The average area of a farm in the valley is about 10 acres. The livestocks are small, usually about $2-5$ cows, $5-20$ sheep, and occasionally a pig and a few hens. The milk yield varies between 2000 $4000 \mathrm{~kg}$ per year.

The feeding is simple, consisting of hay ad libitum supplemented with rations of concentrates.

\section{FIELD WORK AND ANALYTICAL RESULTS}

In order to study a possible relationship between copper and molybdenum levels of herbage and occurring incidences of unthriftiness associated with diarrhoea in cattle, preliminary investigations were carried out in 1957 with 17 samples of hay and grass, collected during the fall of 1957 from "affected farms".

The spectrographic analyses of these material revealed samples with extremely low as well as normal levels of copper, besides normal and relatively high levels, up to 17 p.p.m., of molybdenum, calculated on dry matter basis.

The results from these investigations led to a more comprehensive study of the content of copper and molybdenum in herbage 
and soil in relation to occurring incidences of hypocuprosis in ruminants in this valley.

As a consequence samples of herbage and soil were collected from a greater part of the valley during 1958 (see map). Sampling was carried out in accordance with the technique described later.

The collection of samples consisted of:

64 grass samples from more or less cultivated areas

62 soil

9 grass " " " the mountain grasslands

9 soil

20 rock

The 64 grass samples and the 62 soil samples were taken from 30 different farms. The analytical results are given in tables 1 , 2 and 3.

Unthriftiness with diarrhoea was observed in cattle from 13 of these farms before sampling was started, or occurred in the autumn after sampling was finished. Herbage samples col-

Table 1.

Analytical Figures in Herbage and Soil.

The whole Material collected 1958.

Parts per million in dry Matter.

\begin{tabular}{lcccc}
\hline \multicolumn{1}{c}{ Sample } & Number & Mean & $\begin{array}{c}\text { Standard } \\
\text { Error of Mean }\end{array}$ & Variation \\
\hline Mo herbage & 64 & 4.2 & 0.39 & $14.5-0.8$ \\
Cu herbage & 64 & 6.4 & 0.28 & $10.8-2.5$ \\
Mo soil & 62 & 5.3 & 0.42 & $13.0-0.8$ \\
Cu soil & 62 & 9.9 & 1.37 & $55.0-0.5$ \\
Loss of ignition soil & 62 & 16.4 & 1.96 & $85.8-4.7$ \\
\hline
\end{tabular}

Table 2.

Analytical Figures in Herbage and Soil.

Fen Soil 1958.

Parts per million in dry Matter.

\begin{tabular}{lcccr}
\hline \multicolumn{1}{c}{ Sample } & Number & Nean & $\begin{array}{c}\text { Standard } \\
\text { Error of Mean }\end{array}$ & Variation \\
\hline Mo herbage & 11 & 4.4 & 0.68 & $13.0-2.1$ \\
Cu herbage & 11 & 6.3 & 0.87 & $10.8-2.5$ \\
Mo soil & 10 & 5.4 & 0.96 & $10.0-1.4$ \\
Cu soil & 10 & 18.9 & 5.04 & $55.0-3.0$ \\
pH soil & 10 & 5.05 & 0.170 & $6.8-4.4$ \\
Loss of ignition soil & 10 & 41.2 & 8.47 & $85.8-14.6$ \\
\hline
\end{tabular}


Table 3.

Analytical Figures in Herbage and Soil.

Sand Soil 1958.

Parts per million in dry Matter.

\begin{tabular}{lcccc}
\hline \multicolumn{1}{c}{ Sample } & Number & Mean & $\begin{array}{c}\text { Standard } \\
\text { Error of Mean }\end{array}$ & Variation \\
\hline Mo herbage & 53 & 4.2 & 0.46 & $14.5-0.8$ \\
Cu herbage & 53 & 6.5 & 0.28 & $10.8-2.5$ \\
Mo soil & 52 & 5.3 & 0.46 & $13.0-0.8$ \\
Cu soil & 52 & 8.2 & 1.20 & $38.0-0.5$ \\
pH soil & 52 & 5.27 & 0.470 & $6.25-4.35$ \\
Loss of ignition soil & 52 & 11.6 & 0.52 & $22.0-4.7$ \\
\hline
\end{tabular}

lected during 1957 and 1958 from 9 of these farms revealed molybdenum levels above 3 p.p. m. together with more or less lowered copper values (see table 7). Only on two of these 30 farms we observed incidences which we supposed to be simple copper deficiency. Herbages samples from these farms had molybdenum levels below 3 p.p.m., and the copper levels were extremely low (see table 8).

The 30 farms mentioned above include 6 farms where no symptoms of hypocuprosis were observed until the spring of 1959. The analytical data from these farms, the majority of which are situated in Valle, are shown in table 4. With two exceptions

Table 4.

The Content of Molybdenum and Copper in Herbage from Farms not affected with Hypocuprosis.

\begin{tabular}{cccl}
\hline $\begin{array}{c}\text { Farm } \\
\text { No. }\end{array}$ & $\begin{array}{c}\text { Mo } \\
\text { p. p. m. }\end{array}$ & $\begin{array}{c}\text { Cu } \\
\text { p. p. m. }\end{array}$ & District \\
\hline 1 & 1.8 & 6.3 & Valle \\
& 2.0 & 6.3 & Valle \\
\hline 2 & 1.7 & 6.4 & Valle \\
\hline 3 & 1.2 & 5.0 & Valle \\
\hline 4 & 5.5 & 6.4 & Valle \\
\hline \multirow{2}{*}{5} & 2.8 & 8.1 & \\
\hline & 3.2 & 7.5 & Hovden \\
\hline
\end{tabular}


the herbage samples from these "healthy" farms showed molybdenum values below 3 p.p.m., and all the copper values were above 5 p. p. $\mathrm{m}$. All these farms, with the exception of number 4, had, in 1958, animals in the exposed age group, i. e. pregnant heifers 2-3 years old (see under clinical observations). Both on farm no. 3 and farm no. 4 , conditioned copper deficiency has been observed in 1959 .

When the sampling was started, it was difficult to select farms which were known to be unaffected by hypocuprosis, from where control material could be collected. These 6 farms were assumed to be "healthy" but, obviously, this is not strictly correct. As will be seen from table 4, the mineral levels of molybdenum and copper are close to the dangerous levels given by Cunningham, and this will explain that the content of these elements may have changed to a dangerous level.

We have, however, a number of analyses from different parts of Norway, showing levels of copper and molybdenum of $6-7$ p. p. m., and $0.7-2.0$ p. p. m., respectively, in grass from farms where no symptoms of hypocuprosis have been observed.

Samples from pastures in the mountains did not show abnormal contents of molybdenum and copper, but it must be emphasized that the samples taken were few, and that the areas are wide.

The analyses of rock samples revealed minerals rich in molybdenum, copper and silver.

No distinct correlation between levels of copper and molybdenum in soil and herbage was found. All samples of soil showed a low $\mathrm{pH}$ and the variation in acidity was not very marked. As a consequence, therefore, our attention was more directed to the content of these minerals in the herbage, which is of actual interest in evaluating factors in relation to the disease.

\section{CLASSIFICATION OF SAMPLES OF HERBAGE}

Table 1 shows the analytical data of grass and soil samples from more or less cultivated land. A differentiation of the same data has been given in relation to type of soil in tables 2 and 3 .

It is difficult to classify the samples according to the topography, as the bulk of the samples were drawn from the old river deposits in the bottom of the valley. From the younger, partly submersed deposits close to the river, as well as from the 
typical morena soil and the colluvium on the hill sides, only a few samples were drawn.

We have, however, undertaken a geographical classification of the grass samples collected in 1958 , as seen in table 5 . This

Table 5.

Classification of the Analytical Figures from Herbage Analyses. Material Collected 1958 from more or less Cultivated Land.

\begin{tabular}{|c|c|c|c|c|c|c|}
\hline District & Element & $\underset{\text { ber }}{\text { Num- }}$ & Mean & $\begin{array}{l}\text { Standard } \\
\text { Error of } \\
\text { Mean }\end{array}$ & Variation & $\begin{array}{c}\text { Cases of Deficiency } \\
\text { until the Beginning } \\
\text { of } 19 j 9\end{array}$ \\
\hline \multirow{2}{*}{ Hovden } & Mo & 2 & 2.55 & 0.35 & $2.9-2.2$ & \multirow{2}{*}{ No cases } \\
\hline & $\mathrm{Cu}$ & 2 & 8.20 & 0.20 & $8.4-8.0$ & \\
\hline \multirow{2}{*}{$\begin{array}{l}\text { Bykle } \\
\text { (Tveitvoll) }\end{array}$} & Mo & 2 & 2.15 & 0.05 & $2.2-2.1$ & \multirow{2}{*}{ No cases } \\
\hline & $\mathrm{Cu}$ & 2 & 8.20 & 2.60 & $10.8-5.6$ & \\
\hline \multirow{2}{*}{$\begin{array}{l}\text { Bykle } \\
\text { (Tveiten-Holen) }\end{array}$} & Mo & 5 & 4.84 & 0.81 & $7.1-3.2$ & \multirow{2}{*}{$\begin{array}{l}\text { Cond. copper-def. } \\
2 \text { cases }\end{array}$} \\
\hline & $\mathrm{Cu}$ & 5 & 8.04 & 0.71 & $9.7-6.2$ & \\
\hline \multirow{2}{*}{ Valle } & Mo & 18 & 2.26 & 0.15 & $3.0-1.1$ & \multirow{2}{*}{$\begin{array}{l}\text { Simple copper-def. } \\
10 \text { cases }\end{array}$} \\
\hline & $\mathrm{Cu}$ & 18 & 5.55 & 0.48 & $8.1-2.5$ & \\
\hline \multirow{2}{*}{ Rystad } & Mo & 7 & 3.24 & 1.15 & $9.8-0.8$ & \multirow{2}{*}{$\begin{array}{l}\text { Cond. copper-def. } \\
6 \text { cases }\end{array}$} \\
\hline & $\mathrm{Cu}$ & 7 & 6.54 & 0.92 & $9.8-3.4$ & \\
\hline \multirow{2}{*}{ Sordal } & Mo & 11 & 5.26 & 0.91 & $9.5-1.9$ & \multirow{2}{*}{$\begin{array}{l}\text { Cond. copper-def. } \\
2 \text { cases }\end{array}$} \\
\hline & $\mathbf{C u}$ & 11 & 6.28 & 0.39 & $8.0-4.2$ & \\
\hline \multirow{2}{*}{ Langeid } & Mo & 6 & 6.68 & 2.09 & $13.5-2.4$ & \multirow{2}{*}{$\begin{array}{l}\text { Cond. copper-def. } \\
2 \text { cases }\end{array}$} \\
\hline & $\mathrm{Cu}$ & 6 & 7.28 & 0.96 & $10.8-4.5$ & \\
\hline \multirow{2}{*}{ Ose } & Mo & 6 & 6.10 & 1.89 & $14.5-1.7$ & \multirow{2}{*}{$\begin{array}{l}\text { Cond. copper-def. } \\
3 \text { cases }\end{array}$} \\
\hline & $\mathrm{Cu}$ & 6 & 5.12 & 0.76 & $8.1-3.5$ & \\
\hline
\end{tabular}

table shows that the content of both molybdenum and copper is lower in Valle than in any other district mentioned, with the exception of molybdenum in Tveitvoll. To ascertain whether the difference between Valle and other districts as to the levels of copper and molybdenum are significant, $t$-tests have been carried out according to the Behrens-Fisher method, with Cochrans approximation. The results from the statistical tests are presented in table 6.

According to the analytical values found in the herbage, it may be possible to divide Setesdalen into 3 areas: One characterized by high molybdenum values associated with normal or low copper levels (The districts of Bykle, Rystad, Sordal, Langeid, Ose). 
Table 6.

Molybdenum.

Valle/Hovden

No significant difference

Valle/Bykle (Tveitvoll)

Valle/Bykle (Tveiten-Holen) Significant difference $(P=0.025)$

Valle/Rystad

Valle/Sordal

Valle/Langeid

Valle/Ose

Hardly significant difference $(0.40<\mathrm{P}<0.50)$

Significant difference $(\mathrm{P}=0.01)$

$\begin{array}{lll}\prime & \quad(0.05<\mathrm{P}<0.1) \\ \Rightarrow & (0.05<\mathrm{P}<0.1)\end{array}$

Copper.

Valle/Hovden

Significant difference $(P=0.05)$

Valle/Bykle (Tveitvoll)

No significant difference

Valle/Bykle (Tveiten-Holen) Significant difference $(P=0.05)$

Valle/Rystad

Valle/Sordal

Valle/Langeid

Valle/Ose

No siginficant difference

Significant difference $(P=0.025)$

No significant difference

The second area characterized by extremely low copper values and normal molybdenum values (Valle), and the third area representing normal values of both copper and molybdenum, i.e. districts where neither induced nor simple copper deficiency have been seen.

It must be admitted that the number of samples from some of the districts (especially Hovden and Bykle (Tveitvoll)) is too small to use a statistical procedure but as we wanted to compare also the samples from these districts with those from Valle, we had to use the same method in order to have the same basis of comparison.

\section{CLINICAL OBSERVATIONS}

The first cases of conditioned copper deficiency are generally observed in August, after the cattle have been on pasture since the last part of June or from the early part of July. The following survey, covering the period from September 1957 to February 1959 , includes those cases where copper treatment has been beneficial. Only cases treated after clinical examination are included.

As will be seen from Tables 7 and 8, 40 cases of conditioned and 10 cases of simple copper deficiency are treated. A similar number are treated according to anamnetic information, but they are not included in this survey. 
Disorder in Relation to Season.

Observations have been made from September 1957 to February 1959 , but seasonal variations can only be calculated on the basis of 1958 when 23 cases of conditioned copper deficiency were treated, out of which 21, or 91 per cent, occurred in the period August-November. The peak month was November with 12 cases, or 52 per cent. For cases treated later we usually have anamnetic information showing that the disease had developed in the late autumn. Thus, in Setesdalen, conditioned copper deficiency seems to be a typical autumnal disease. No statement about the seasonal variation could be made in cases of simple copper deficiency, as the number of cases is too small.

Disorder in Relation to Age.

The age of the cows suffering from conditioned copper deficiency, varies between 6 weeks and 6 years, with an average of 2.7 years. 13 cows, or 33 per cent, were about two years, 9 cows, or 23 per cent, were about three years old.

The age of the cows suffering from simple copper deficiency, varies from a half to two years, with an average of 1.4 years.

Disorder in Relation to the State of Pregnancy.

22 animals, or 55 per cent the total suffering from conditioned copper deficiency, were treated in a period ranging from 30 days before to 30 days after calving. 16 of these cows, i.e. 40 per cent, were between 2 and 3 years. Naturally, the last part of the pregnancy makes heavy demands upon the copper stores in the cow, as the calf needs to build up a copper reserve for its first weeks of post-natal life. Moreover, the milk production, after calving, requires a good appetite and, as a consequence, the disease is more easily realized in this period, although it has actually been present in the latter part of the pregnancy. All cows treated for simple copper deficiency, were under two years, and in 50 per cent of the cases the disease occurred closely associated with calving.

\section{Diarrhoea.}

In affected cows in the area where the molybdenum content of the herbage is on the high side, diarrhoea is nearly always an invariable symptom. 33 out of 40 cows, or 83 per cent, had diarrhoea. According to our observations it seems that diarrhoea 


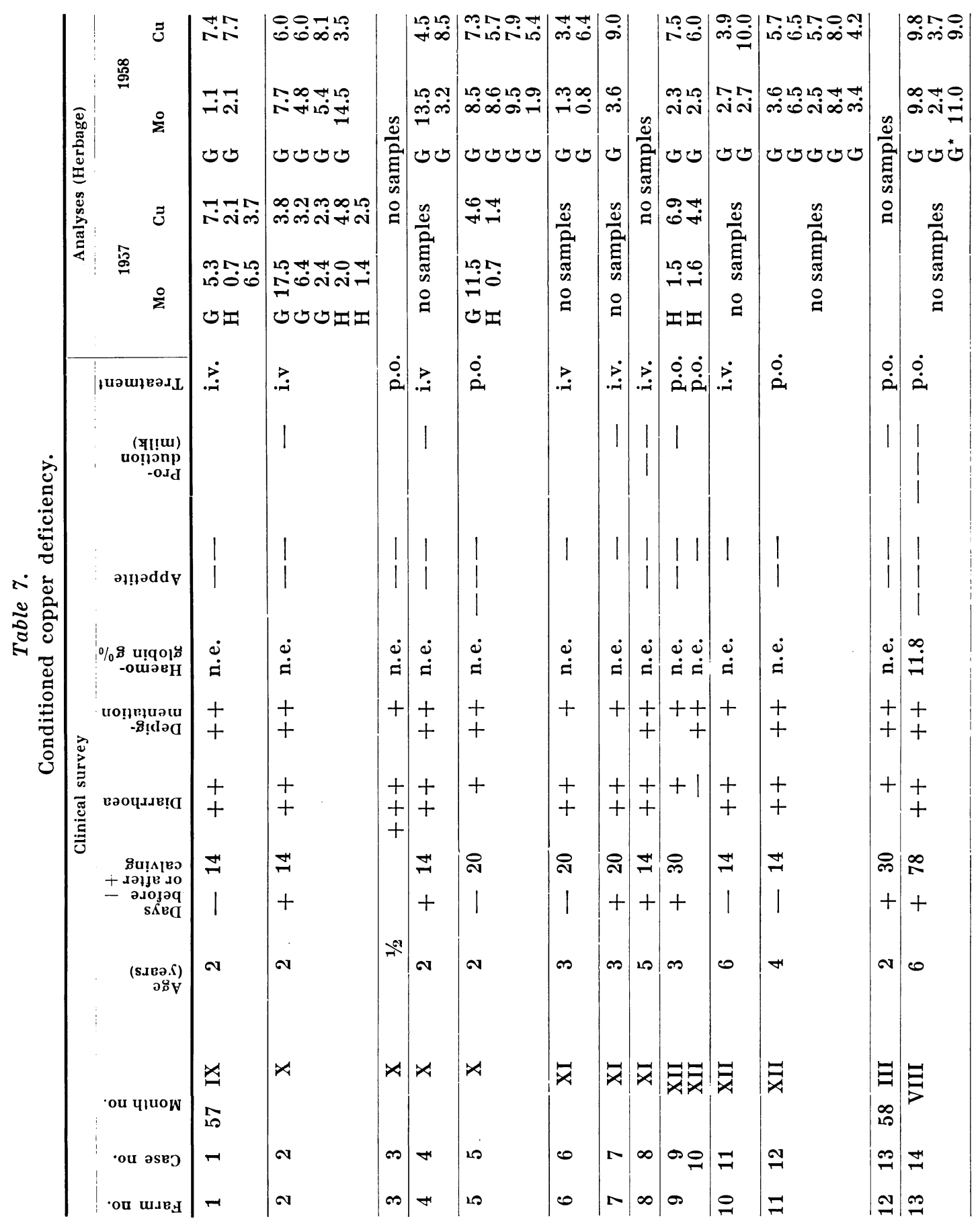




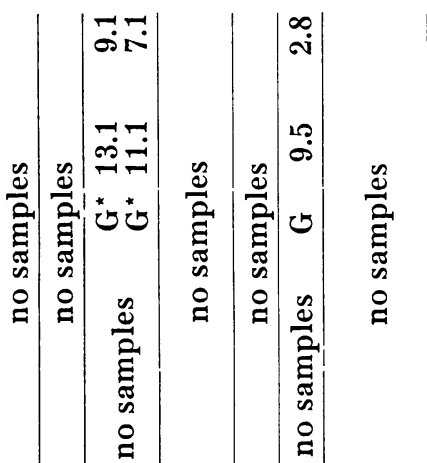

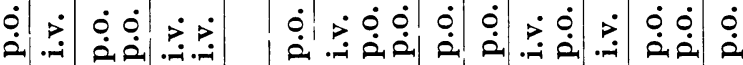

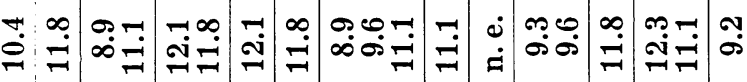

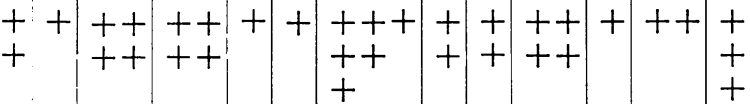

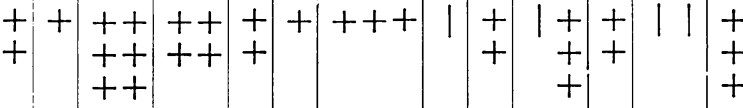

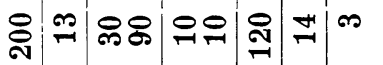

$++1+1+1+$

:

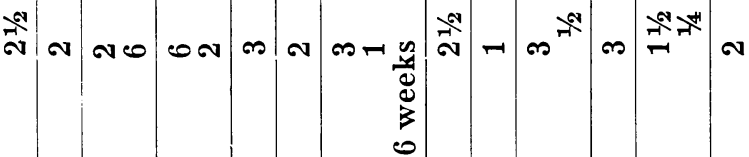

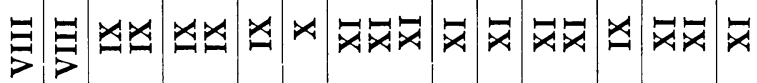

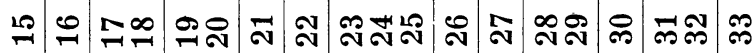

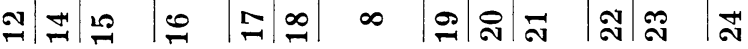

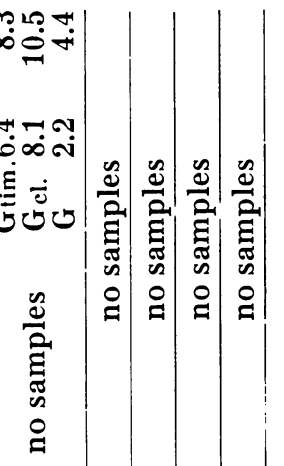

$\dot{0}: \dot{0} \dot{0} \quad \dot{0} \dot{0} \dot{0} \dot{0}$

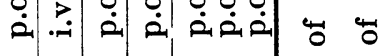

苾

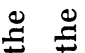

$\sum_{D}^{\infty} \sum^{\infty}$

$\begin{array}{r}\infty \\ +\quad 1.90 \\ \hline\end{array}$

4 世

வ

吉总泀

$+++++++$

$+++++$

$+++11+$

$++$

\#

$+++1+1$

$\infty \cos$

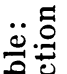

苋

.

$\stackrel{\pi}{\sim} . \stackrel{ \pm}{*}$

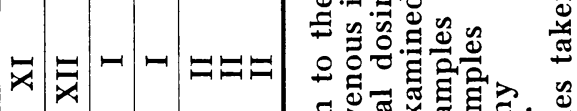

is

ฝึ

เู่ 


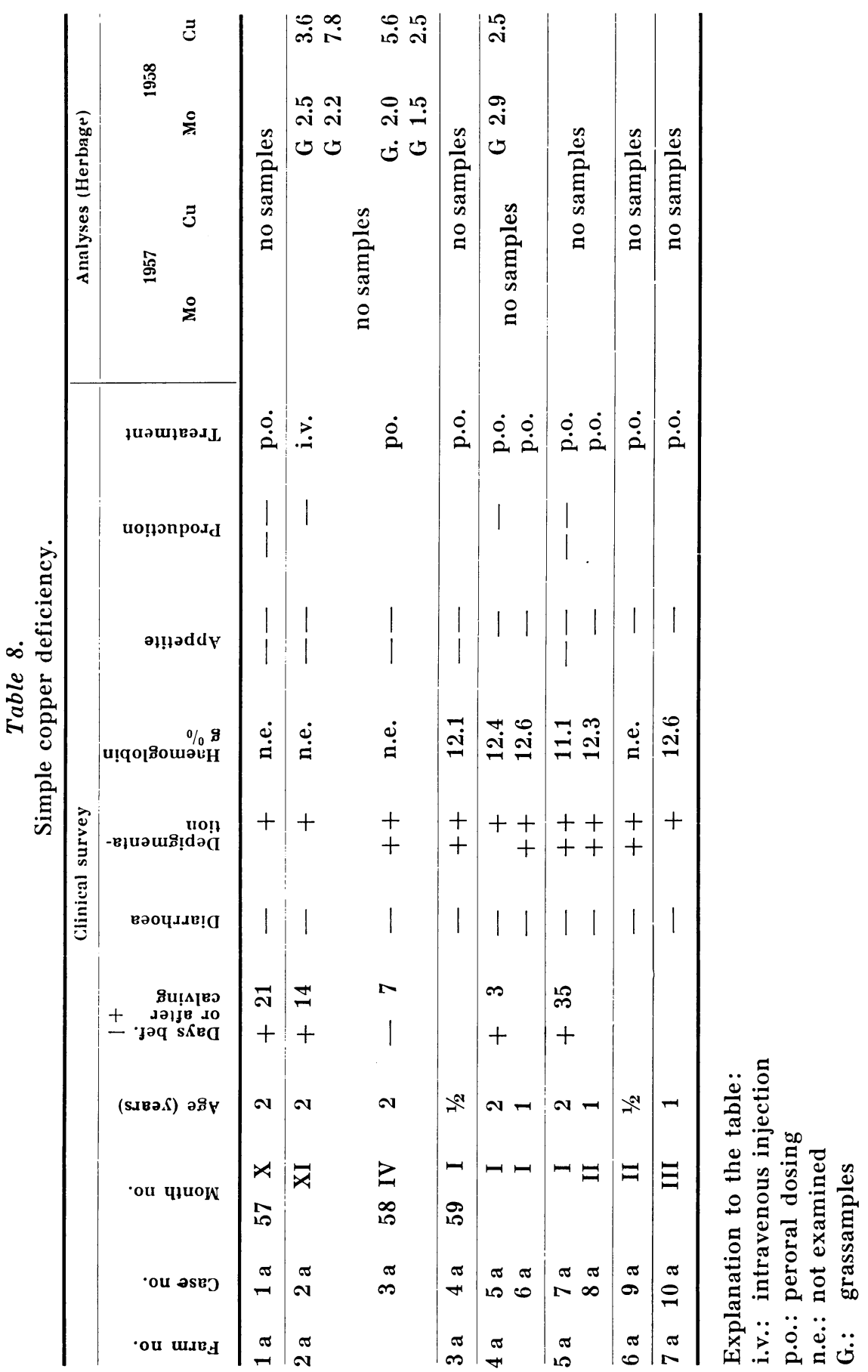


can be induced by reducing the water supply, and this is probably the reason why scouring mostly occurs the first week after stalling. Diarrhoea may occur periodically and may occasionally be stinking. The degree of diarrhoea is not proportional to the other symptoms.

In the district where simple hypocuprosis occurs, none of the animals were affected with diarrhoea.

\section{Depigmentation of the Hair-layer.}

The first obvious symptom, is a depigmentation of the hairlayer around the eyes and on the cheecks. The hair-layer gets a faded khaki-coloured appearance. Subsequently this fading spreads towards the neck. A distinct line can sometimes be observed between the normal and the faded areas. At times the khaki-coloured parts look like an island, about the size of a hand, in the red or redbrown areas.

\section{Haemoglobin Values.}

As copper acts as a catalyst in the production of haemoglobin, facilitates the absorption from the gastro-intestinal tract and moreover plays an essential role in enabling iron derived from the breakdown of red blood cells to be used again in the formation of new cells, one should expect anaemia in connection with all kinds of copper deficiency.

According to Cunningham, several authors have found a microcytic hypocromic anaemia associated with experimentally produced copper deficiency in rats, rabbits and pigs. According to Field (1957), lowered haemoglobin values are not an invariable symptom in copper deficiency; it depends upon the degree of the deficiency. The same author found in April, before the cattle were turned out on a pasture producing conditioned copper deficiency, a mean haemoglobin value of $11.81 \mathrm{~g}$ per cent (10.83 -12.78). When the cattle were kept on this pasture, the values fell gradually until, in September, the mean value reached $8.34 \mathrm{~g}$ per cent (6.1-10.9). According to Duke, (1955), $12.03 \mathrm{~g}$ per cent is considered to be a normal haemoglobin value. We found a mean haemoglobin value of $11.99 \mathrm{~g}$ per cent (10.66-12.73) in 11 healthy cows. The mean age of these animals was two years. By determination of the haemoglobin content in 25 cows, suffering from conditioned copper deficiency, we found a mean value of $10.98 \mathrm{~g}$ per cent $(8.88-12.29)$. 
If we accept the values found by Field, in April, as being normal, with $10.83 \mathrm{~g}$ per cent as the lowest, ten of our animals, or $40 \mathrm{~g}$ per cent of those examined, had a lower value than the lowest registered by Field in April. Compared with our lowest found normal value, 8 cows, or 32 per cent, had a lower haemoglobin level. Haemoglobin values from 6 cows suffering from simple copper deficiency showed a mean value of $12.17 \mathrm{~g}$ per cent $(11.1-12.58)$. None of these values are below the lowest found by Field. It thus seems likely to be a tendency that lowered haemoglobin values are associated with conditioned copper deficiency, though it is not an invariable symptom.

\section{Appetite.}

The appetite is always reduced. It is usually this considerably reduced appetite, sometimes combined with diarrhoea, which calls the farmer's attention to the fact that something is wrong. The appetite may be almost completely lost, or it may be more or less reduced, but an improvement is always observed immediately after treatment. If the disease occurs on pasture, the cattle are seen grazing lazily, eating only a bit here and a bit there. If occurring while the animals are stalling, they will take a couple of mouthfuls immediately after the hay has been brought to them; then they start stirring the hay, and finally throw it away by the horns. The animals will still eat cake-meal for a while.

\section{Milk Prduction.}

The milk yield will always be reduced, depending more or less upon the period of absent appetite. The reduction may range from small amounts up to half of the normal yield. The reduction is usually estimated on the basis of the increase in the yield after treatment.

\section{Disturbances in the Sexual Cyclus.}

The absence of oestrus was observed in all three cows treated later than 150 days after calving (Cases Nos. 15-26-28, Table 7 ). It is still difficult to decide whether other forms of sterility are associated with copper deficiency in Setesdalen. No essential difference has been found in the repeat breeding frequency on farms with and without any forms of copper deficiency. Experiments of treatment with copper sulphate have not given observable results. 


\section{Other Changes of the Normal State.}

Loss of condition and bad growth gain are typical symptoms associated with either forms of copper deficiency. An animal of three years generally has the size of a two year old beast. Skeleton disturbances, as observed in Australia and East-Anglia, have not been observed in Setesdalen. The animals were easily movable and had no difficulties in rising. Very often the temperature was found to be lower than normal $\left(37.8-38.2^{\circ} \mathrm{C}\right)$.

\section{COPPER DEFICIENCY IN SHEEP}

Apart from reduced growth gain and lowered appetite, the clinical symptoms of copper deficiency in sheep are difficult to define. Cases of diarrhoea, curable with copper doses, have occurred in the areas of conditioned copper deficiency.

Wool deformations described by other authors, are not easy to observe in Setesdalen. Individual variations in Norwegian sheep breeds with respect to crimps and glassy appearance are so great that a judging of these features may be of very little value.

It may be taken into account that sheep in Setesdalen are usually grazing in the mountain regions from May to September, during which time they have an opportunity to build up their copper reserves protecting also against conditioning factors.

In more livestocks, especially those from the areas of conditioned copper deficiency, bad growth gain and lowered appetite have been observed in the young animals. Dwarfed individuals can also be seen. Administration of copper in these livestocks has had a dramatic effect.

Seven cases of lambs showing a clinical picture quite similar to enzootic ataxia (Swayback) were observed in 1958. One of these lambs recovered in three weeks after receiving small doses of copper and coercive feeding. Another one also survived, but did not recover entirely; the only treatment in this case was coercive feeding. The remaining five lambs died. A histological examination was carried out on two of them, revealing a demyelination of cerebrum, mainly located to the medullar substance, in the one lamb, and in the other one, smaller, focal proliferations of gliacells. This examination was carried out by the Department of Pathology at the Norwegian Veterinary College.

About half of the livestocks in the areas of copper deficiency were dosed with copper during the winter 1958-1959. In all 
cases the owners reported increasing appetite and thriftiness. This effect has been particularly pronounced in lambs born in the spring 1959. In the copper administered livestocks, no cases of swayback occurred, while 30 cases of clinical swayback occurred in the untreated livestocks.

\section{TREATMENT}

Prevention and treatment of copper deficiency may be achieved by increasing the copper content of the herbage or by administering copper to the animals. Copper sulphate as fertilizer, amounting to $5-20 \mathrm{lbs}$./acre, has been in use in Australia. This has been assumed to protect the animals for up to two years but, the method is expensive. Licks are cheaper and simpler. In New Zealand it has been found that licks containing 0.5 per cent copper sulphate are sufficient to protect against enzootic ataxia.

But as not all of the animals tage advantage of the lick, the method is uncertain. To obtain reliability and control it is better to supply every animal separately. With cattle this is feasible, but with sheep it is more difficult. It is also possible, however, to add small supplies in the drinking water or in a paste.

Peroral Dosing with Copper Sulphate.

Henderson (1957) applied to cattle $5 \mathrm{~g}$ copper sulphate three times with 5 days interval, but the cows had recidives after a couple of months. It is better to give a monthly dose of $5 \mathrm{~g}$ in addition. The tolerance for copper is high in cattle, but the ability of excreting copper is limited. Todd \& Gracey (1959) reported death of an 8 months old heifer supplied with $2 \mathrm{~g}$ copper sulphate daily for five months. Sheep are more sensitive to copper, and caution should be taken in the treatment. Large doses of copper with long intervals are safer than small doses daily. An overdosing will then always result in diarrhoea. Diarrhoea will also result if 5-10 g copper sulphate is supplied to cattle, or $1-2 \mathrm{~g}$ to sheep, not suffering from copper deficiency. Haemoglobinuria associated with copper dosing has only been observed once by us: Through a misunderstanding of the owner, a cow, injected with 0.5 g copper sulphate i.v. was given 5 g copper sulphate orally the next day.

We have tentatively given $1 \mathrm{~g}$ copper sulphate three times during pregnancy to sheep. According to the literature, the doses 
for sheep can vary considerably, from three times 2.5 g copper sulphate in the middle period of pregnancy with a fortnightly interval, to $1 \mathrm{~g}$ copper sulphate one week before lambing, to control "Swayback" (Cunningham).

\section{Intravenous Dosing of Copper Sulphate.}

The safest dosing method is intravenous injection, and in cattle this is feasible. Field, thus, administered $0.35 \mathrm{~g}$ copper sulphate by intravenous injection to five cows, and three of these, as late as 7 months after injection, had normal copper values in the blood. Henderson used $50 \mathrm{mg}$ copper in $100 \mathrm{ml}$ water, and in four cases respiratory disturbances, lasting for 24 hours, were observed.

We have treated 17 cows with copper sulphate administered intravenously. The doses have been $0.3-0.5 \mathrm{~g}$ copper sulphate in $500 \mathrm{ml} 5$ per cent glucose solution. It was quite surprising to observe the rapid increase in appetite as well as the rapid cessation of the diarrhoea, even after oral dosing. By intravenous dosing the appetite recovers immediately and faeces may be normal after 6 hours. In no case have we observed any undesired reaction immediately after injection. In one case urticaria was observed 24 hours after injection. One cow, not suffering from copper deficiency, developed tympany after the injection. The symptoms lasted for 24 hours.

\section{DISCUSSION}

In the district of Valle, extremely low copper figures besides normal molybdenum figures have been found in the herbage and in this district only the cases of simple copper deficiency were observed. From the 7 farms giving rise to simple copper deficiency, 2 are sampled.

Conditioned copper deficiency prevails in the districts of Bykle (Tveiten-Holen, Rystad, Langeid, Sordal and Ose). Herbage samples from these areas are characterized by rather high molybdenum levels associated with normal or subnormal copper levels.

A total of 40 cases of conditioned copper deficiency, occurring on 29 farms, and 10 cases of simple copper deficiency, arising from 7 farms, are described.

As will be seen from Table 7, 13 of the 29 farms giving rise 
to conditioned copper deficiency are sampled, and on these 13 farms, 15 cases occurred.

In Setesdalen, we usually find 10-15 farms grouped closely together where the topographical conditions render settlement possible. As the farms are small, the soil and the herbage on all the farms in one group are fairly homogenous, and there are no essential difference in the mode of farming and agriculture. With one exception we have samples from all groups and it seems, therefore, reasonable to assume that samples from missing farms inside a group would have shown analytical figures of the same order.

As mentioned previously, Cunningham considers copper values above 5 p. p. m. as being sufficient if conditioning factors are not present, and molybdenum values below 3 p. p.m. as being harmless. $3-10$ p. p. m. molybdenum in the herbage is considered harmful if the copper content is on the low side, and more than 10 p. p. m. as harmful if the copper content is normal.

From Table 8 is seen that on the 2 sampled farms giving rise to simple copper deficiency all molybdenum values are below the harmful limit 3 p.p.m., and 3 of the copper figures are below 5 p.p.m.

From Table 7 is seen that of the 13 sampled farms giving rise to conditioned copper deficiency, 9 farms have samples with molybdenum figures above $3 \mathrm{p}$. p. m. with a maximum value of 17 p. p. m. 4 farms, viz. Nos. 6, 7, 9 and 10, have molybdenum values below 3 p. p. m. It must be emphasized that these samples were taken in the early summer, and we assume the molybdenum and copper content of the herbage to be subject to seasonal variations. Field, (1957), who examined four pastures in East-Anglia with 2-3 weeks interval, found that the molybdenum content increased and the copper content decreased during the period from May to September. He states, therefore, that during this period there was an inverse relationship between the copper and molybdenum content of herbage from these fields. The few samples collected from the pastures and meadows in October 1957 and August 1958 show a considerable higher molybdenum content than samples from the same places collected at the end of June and the beginning of July. Most authors also agree that the molybdenum content of the vegetation increases during rainy periods. The samples from Setesdalen were collected after a dry period; a rain period commenced during the sampling. 
Considering these influences upon the molybdenum content of the herbage, and with the normal or low copper values in the same, the analytical results seem to correspond fairly well with the clinical observations, when Cunningham's figures are used as a norm.

Though it is difficult to exclude other inducing factors, molybdenum is likely to be an important conditioning factor in complicated hypocuprosis in Setesdalen. Further research work is going on.

It may be objected to molybdenum as a conditioning factor on the ground that the disease in some cases occurred after stalling and in a few cases as late as in February. From these farms, however, anamnetic information showed unthrifty animals already in the autumn.

It might as well have been expected that more cases of copper deficiency would have occurred during the autumn 1958 on those farms where increased molybdenum content and/or low copper content was found in the herbage. But, the following points should be borne in mind:

1. In the autumn three of the farms were selected for an experiment with copper supplement to the diet and no hypocuprosis developed on these farms.

2. One of the farms has no cattle any longer.

3. As mentioned before, we have found that 2-3 years old pregnant heifers are particularly exposed to conditioned copper deficiency. The farms in Setesdalen are small, with $2-5$ cows each, and farms of this size do not have pregnant heifers every year.

Our findings have led to a more thoroughly planned study of the seasonal mineral variations in relation to weather conditions. Results of this study will be published later. The influence of other minerals in relation to disorder, especially sulphur, needs also to be considered. In addition, it seems logical to give a survey of the mineral content of already collected samples of blood and liver from diseased animals.

\footnotetext{
SAMPLING TECHNIQUE AND ANALYTICAL METHODS Sampling Technique.

On each farm where sampling was undcrtaken, one, two or more pieces of land were selected for sampling, in order to get samples from all the different types of soil represented on the farm. The sampling technique was as follows:
} 
On 10-15 spots of each piece of land, depending on the area, a small amount of grass was cut, and on exactly the same spot a sample of soil was drawn with a soil sampler (an auger). Sample depth $15-20 \mathrm{~cm}$. All the herbage samples from one piece of land were collected in a paper bag, and all the soil samples in a polythen plastic bag.

In the few cases we were faced with a pure timothy-clover meadow, timothy and clover were sampled separately.

For each sampling field the following information was secured:

A rough statement of the botanical composition. Altitude above sealevel - Description of the ground. Drainage - Possible submersion - Geological origin. Soil type - Depth of the top-soil layer and the humus content. Colour of the soil just underneath the top soil layer. Age of the cultivated land, and what was growing there previously. Possible rotation of crop - Information about fertilizing. Age of the actual meadow and what was seeded in it. For every farm, information was collected about the size of the livestock, the average yield of milk in a year, and the feeding.

The samples were sent in fresh state to the laboratory where both the soil and the herbage samples were airdried. After drying, the herbage samples were ground in a hammermill, while the soil samples were sieved through a $2 \mathrm{~mm}$ iron sieve, and then mixed carefully.

The samples were now ready for the analytical procedure.

\section{Analytical Procedure.}

The determination of molybdenum and copper in soil and herbage is carried out as semiquantitative spectrographic analyses. The procedure is mainly according to Mitchell (1948). A short description is given below:

\section{Plant Material.}

About $1.5 \mathrm{~g}$ of air-dried material is dried overnight (18 hours) at $80^{\circ} \mathrm{C}$ in a silica crusible and then ashed in an electric muffle furnace at $450^{\circ}$ for $2-3$ hours. The ash is kept in a $\mathrm{K}_{2} \mathrm{CO}_{3}$-saturated hygrostate for 24 hours and then weighed. The loss of moisture and the ash percent are calculated. The ash is mixed with one part of graphite powder and filled in a graphite electrode with boring dimensions $0.8 \times 8 \mathrm{~mm}$.

Soil.

The air-dried soil is ground in an agate mortar and $0.9-1 \mathrm{~g}$ of the material is ashed in an electric muffle furnace at $650^{\circ} \mathrm{C}$ in a silica crusible for $1 / 2$ hour. (Ignition beyond this time does not lower the weight markedly). The ash percent and loss of ignition are calculated.

Filling of electrodes as for plant material.

\section{Equipment and Arcing Procedure:}

Instrument: Hilger Large Spectrograph, type E 492.

Exposing conditions: Cathode layer arc with a Hilger Lens F 958 set 
$28 \mathrm{~cm}$ in front of the slit, producing an image of the arc at the slit.

Each sample arced $3 \times 1 \mathrm{~min}$. (fractionating) and on each plate 9 spectra, i.e. 3 samples are taken.

The arc length $10 \mathrm{~mm}$ - Slit width $0.01 \mathrm{~mm}$ - current 9 amp.

Wawelength $2480-3600$ A.

Plates: Ilford Chromatic, backed, developed for $2 \frac{1 / 2}{2}$ min. in I. D. 2 developer at $18^{\circ} \mathrm{C}$.

Reading of the Plate:

The following lines are read: Mo $3170.3 \AA$

$\mathrm{Cu} 3247.5 \AA$

The plates are read in a Judd-Lewis comparator against standard plates. The plates are prepared by arcing special standard-mixtures. Our standard mixtures are mainly according to Mitchell. A short description of the composition is given:

Plantash Standard: The base has about this composition:

$18 \% \mathrm{CaCO}_{3}-18 \% \mathrm{KH}_{2} \mathrm{PO}_{4}-20 \% \mathrm{~K}_{2} \mathrm{SO}_{4}-$ $16 \% \mathrm{~K}_{2} \mathrm{CO}_{3}-8 \% \mathrm{Na}_{2} \mathrm{CO}_{3}-5 \% \mathrm{MgO}-20 \%$ $\mathrm{SiO}-0.3 \% \mathrm{Fe}_{2} \mathrm{O}_{3}-0.3 \% \mathrm{Al}_{2} \mathrm{O}_{3}$

To this base are added a total of 14 trace elements in concentrations from $1 \%$ to 1 p. p. m.

Soilash Standard: The base has about this composition:

$63 \% \mathrm{SiO}_{2}-20 \% \mathrm{Al}_{2} \mathrm{O}_{3}-5 \% \mathrm{Fe}_{2} \mathrm{O}_{3}-3,6 \%$

$\mathrm{CaCO}_{3}-2 \% \mathrm{MgO}-3.5 \% \mathrm{Na}_{2} \mathrm{CO}_{3}-3.5 \%$ $\mathrm{K}_{2} \mathrm{SO}_{4}-1 \% \mathrm{TiO}_{2}$

The mixture is sintered in a muffle at $1000^{\circ} \mathrm{C}$. To the base are added a total of 30 trace elements in concentrations from $1 \%$ to 1 p. p. m.

The accuracy of the method is about $\pm 30 \%$.

Determination of $\mathrm{pH}$ in the Soil.

$\mathrm{pH}$ was determined in air-dried and sieved soil. $20 \mathrm{~g}$ soil was shaked with $50 \mathrm{ml}$ water for 1 hour (for fen soil samples, more water was necessary). The suspension was set aside overnight, and after a quick shaking next day, the $\mathrm{pH}$ was determined in the suspension with a Radiometer pH-meter, type P H M 24.

Glass electrode and Calomel electrode.

Determination of Haemoglobin Values.

The blood is taken from the jugular vein after an initial tapping of $40 \mathrm{ml}$ blood for copper determination. The haemoglobin values are determined with a Sicca haemometer and calculated according to the English B S I - standard (100 \% B S I = $14.8 \mathrm{~g} \%)$.

\section{ACKNOWLEDGEMENT}

The authors are indebted to The Agricultural Research Council of Norway for financial support and would like to express their sincere thanks. 


\section{REFERENCES}

Allcroft, R. \& I. C. Buxton: Vet. Rec. 1955, 67, 273.

Allcroft, R.: Report from Seminar on Control of Diseases in Cattle and at Pasture 1957, p. 113.

Cunningham, I. J.: Advances in Vet. Sci. 1955, 2, 138.

Dick, A. T.: Austr. Vet. J. 1952, 28, 30.

Dick, A. T.: Ibid. 1953, 29, 18.

Dick, A. T.: Ibid. 1953, 29, 233.

Duke, H. H.: The Physiology of Domestic Animals, 1955.

Ender, F.: Norsk Vet. Tidsskrift 1942, 1, 2 \& 3.

Ferguson, W. S., A. H. Lewis \& S. J. Watson: Nature 1938, 141, 553.

Ferguson, W. S., A. H. Lewis \& S. J. Watson: J. Agr. 1943, 33, 44.

Ferguson, W. S., A. H. Lewis \& S. J. Watson: Jealots Hill Research. Sta. Bull. No. 293, 1945.

Field, H. I.: Vet. Rec. 1957, 69, 788.

Field, H. I.: Ibid. 1957, 69, 832.

Henderson, M. B.: Canad. J. Comp. Med. 1957, 21, 332.

Kummen, Th.: Jordbunnsbeskrivelse nr. 12, 1916. Det Kgl. Selskap for Norges Vels Jordbunnsutvalg, Norway.

Lewis, A. H.: J. Agr. Sci. 1943, 33, 52, 58.

Mitchell, R. L.: Technical Communication No. 44, 1958. Commonwealth Bureau of Soil Science, England.

Neumann, H.: Norges Geologiske Unders $\varnothing$ kelse nr. 191, 1955, p. 18.

Parker, W. H. \& T. H. Rose: Vet. Rec. 1955, 67, 276.

Robertson, A.: Ibid. 1957, 69, 651.

Todd, J. R. \& I. F. Gracey: Ibid. 1958, 70, 238.

Todd, J. R. \& I. F. Gracey: Ibid. 1959, 71, 145.

\section{SUMMARY}

In Setesdalen, a valley in the Southern part of Norway, conditioned copper deficiency as well as simple copper deficiency have been found in cattle. The authors describe 40 cases of conditioned copper deficiency and 10 cases of simple copper deficiency. The occurrence of simple copper deficiency is limited to one district only, while the conditioned copper deficiency is found in different parts of the valley.

Spectrographic analyses are carried out of grass, hay and soil from the area. These analyses show molybdenum contents up to 17 p. p. m. in grass from the area with conditioned copper deficiency. In the district of simple copper deficiency, the highest molybdenum figures found are 3 p. p. m. The copper values in grass from the area of conditioned copper deficiency are normal or slightly subnormal, with an average of about $6.6 \mathrm{p}$. p. m. In the district of simple copper deficiency they are generally lower, with an average of about $5.5 \mathrm{p}$. p. m. Statistic tests of significance are carried out on the mineral variations between the separate districts. The good agreement between clinical observations and analytical results is discussed.

The symptoms of conditioned copper deficiency and simple copper deficiency are fairly equal, with the expection of diarrhoea, which 
is not observed in any cases of simple copper deficiency, but in 83 per cent of the cases of conditioned copper deficiency. Skeleton disturbances associated with copper deficiency are not observed in Setesdalen.'A marked lowering of the haemoglobin values is not proved as a invariable symptom. Other symptoms are lack of appetite and unthriftiness, decreased yield of milk, and fading of the hair-layer, especially in the face and on the neck.

Cases of enzootic ataxia (Swayback) are seen in the copper deficient area. In sheep, a lot of other cases, presumably due to copper deficiency, have also been observed. The treatment has been administration of copper supplies orally or by intravenous injection, results of which have been discussed.

Finally a survey of the sampling technique and analytical methods is given.

\section{ZUSAMMENFASSUNG}

Das Vorkommen von bedingtem und einfachem Kupfermangel beim Rind und Schaf im Setesdalen, einem Tal des südlichen Norwegens.

Die Verfasser haben bei Rindern im Setesdalen in Südnorwegen 40 Fälle von bedingtem Kupfermangel und 10 Fälle von einfachem Kupfermangel nachgewiesen. Die Fälle einfachen Kupfermangels beschränken sich auf ein einziges Gebiet, während die Fälle bedingten Kupfermangels in mehrere Gebieten des Tales vorkommen.

Es wurden spektrographische Analysen von Heu, Gras und Erde ausgeführt. Diese Analysen zeigen einen Molybdängehalt bis zu 17 p. p. m. in Gras aus Gebieten mit bedingtem Kupfermangel. In demjenigen Gebiet, in velchem einfacher Kupfermangel ermittelt wurde, betrug der höchste Molybdängehalt 3 p.p.m. Der Kupfergehalt im Gras aus Gebieten mit bedingten Kupfermangel war normal oder etwas niedriger als normal, mit einem Durchschnittswert von 6.6 p. p. m.

Im Gebiet mit einfachem Kupfermangel war der Kupfergehalt durchweg niedriger, mit einem Durchschnittswert von 5.5 p. p. m.

Der Unterschied im Kupfer- und Molybdängehalt zwischen den Vegetationsproben aus den verschiedenen Gebieten ist statistich behandelt. Es gab sich eine gute Uebereinstimmung zwischen den klinischen Beobachtungen und den analytischen Resultaten.

Die Symptome bei bedingtem und bei einfachem Kupfermangel sind ziemlich gleich, abgesehen von Diarrhöe, die in keinem Falle von einfachen Kupfermangels nachgewiesen wurde, dagegen in $83 \%$ der Fälle bedingten Kupfermangels. Skelettveränderungen im $\mathrm{Zu}$ sammenhang mit Kupfermangel wurden im Setesdalen nicht beobachtet. Eine deutliche Senkung der Hämoglobinwerte wurde in einer Reihe von Fällen wahrgenommen, die jedoch kein konstantes Symptom bildet. Andere Erscheinungen sind Appetitmangel und Symptomen von Untriftichkeit, verminderter Milchertrag und Erblassen des Haarkleides, besonders im Gesicht und abvärts am Halse. 
Ferner wurden Fälle von "Swayback" in den Kupfermangelgebieten beobachtet. Ebenfalls kam eine Reihe anderer Krankheitsfälle beim Schaf vor, bei denen Kupfermangel als Ursache vermutet wird. Die Behandlung bestand in der Zufuhr von Kupfer per os oder intravenös; die Resultate derselben werden diskutiert.

Schliesslich wird eine Uebersicht über die Technik der Probenentnahme und die analytische Methodik gegeben.

\section{SAMMENDRAG \\ Forekomst af betinget og enkel koppermangel $i$ Setesdalen, en dal $i$ Syd-Norge.}

Forfatterne beskriver 40 tilfelle av betinget koppermangel og 10 tilfelle av enkel koppermangel hos storfe, påvist i Setesdalen i SydNorge. Tilfellene av enkel koppermangel er begrenset til ett omrâde, mens tilfellene av den betingete koppermangel forekommer over flere områder i dalen.

Det er utf $\varnothing \mathrm{rt}$ spektrografiske analyser av $h \emptyset y$, gras og jord. Disse analyser viser molybdeninnhold opp til 17 p. p. m. i gras fra områder med betinget koppermangel. I området hvor enkel koppermangel er påvist, er det høyest fundne molybdeninnhold 3 p. p. m. Kopperinnholdet $\mathrm{i}$ gras fra områder med betinget koppermangel ligger normalt eller litt lavere enn normalt, med en gjennomsnittsverdi på 6.6 p. p. m.

I området med enkel koppermangel, er kopperinnholdet jevnt over lavere, med en gjennomsnittsverdi på 5.5 p. p. m.

Forskjellen i kopper- og molybdeninnhold mellom de forskjellige områder i dalen er behandlet statistisk. Det er god overensstemmelse mellom kliniske observasjoner og analytiske resultater.

Symptomene ved betinget og enkel koppermangel er temmelig like, bortset fra diarré, som ikke er observert ved et eneste tilfelle av enkel koppermangel, men derimot ved $83 \%$ av tilfellene av betinget koppermangel. Skjelettforstyrrelser i forbindelse med koppermangel er ikke iakttatt i Setesdalen. En markert senkning av haemoglobinverdiene er påvist $i$ en del tilfelle, men er ikke noe konstant symptom. Andre symptomer er appetittmangel og utrivelighet, nedsatt melkeytelse og avbleking av hårlaget, spesielt $\mathrm{i}$ ansiktet og nedover halsen.

Tilfelle av Swayback er også påvist i koppermangelområdene. Likeledes en del andre sykdomstilfelle hos sau, hvor en antar at koppermangel er årsaken.

Behandlingen har vært koppertilf $\varnothing$ rsel per os eller intraven $\varnothing s t$, og resultatene av denne er diskutert.

Til slutt gis en oversikt over prøvetakingsteknikken og den analytiske metodikk.

(Received January 30. 1960). 